\title{
Cosmologies of the ancient Mediterranean world
}

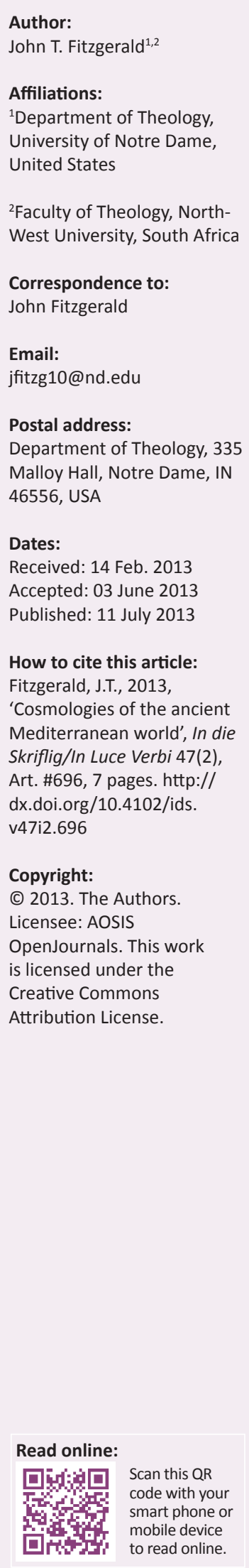

Cosmology is concerned with the order of the universe and seeks to provide an account, not only of that order, but also of the mind or reason behind it. In antiquity, the cosmos was usually understood religiously, such that the cosmologies of the ancient Mediterranean world were either religious in nature or constituted a reaction to a religiously conceived understanding of the structures of the universe. The oldest form in which ancient cosmologies occur is myth, which, owing to its elasticity as a form, enabled them to be appropriated, adapted and used by different groups. In addition, different cosmologies co-existed within the same ancient culture, each having an authoritative status. This article provides an introductory overview of these cosmological myths and argues that a comparative approach is the most fruitful way to study them. Emphasis is given to certain prominent cosmological topics, including theogony (the genesis of the divine) or the relationship of the divine to the cosmos, cosmogony (the genesis of the cosmos), and anthropogony (the origin of humans within the cosmos). Although these myths vary greatly in terms of content and how they envision the origin of the cosmos, many of them depict death as part of the structure of the universe.

Kosmologieë van die antieke Mediterreense wêreld. Kosmologie het te doen met die orde van die heelal en wil rekenskap gee van hierdie orde en ook van die bewussyn daaragter. In die antieke tyd is die kosmos gewoonlik godsdienstig verstaan, met die gevolg dat die kosmologieë van die antieke Mediterreense wêreld óf 'n godsdienstige aard gehad het óf bestaan het uit 'n reaksie op 'n godsdienstig-geskepte begrip van die strukture van die heelal. Mites was die oudste vorm waarin antieke kosmologieë voorkom wat vanweë hulle plooibaarheid dit bewerk het dat hierdie kosmologieë deur verskillende groepe toegeëien, aangepas en gebruik kon word. Hierbenewens het verskillende kosmologieë in die antieke kultuur langs mekaar bestaan - elkeen met sy eie gesagstatus. Hierdie artikel bied 'n inleidende oorsig oor hierdie kosmologiese mites en redeneer dat 'n vergelykende benadering die mees geskikte vir die bestudering van hierdie mites is. Daar word op sekere prominente kosmologiese temas gefokus, waaronder teogonie (die ontstaan van die goddelike) of die verhouding tussen die goddelike en die kosmos, kosmogonie (die ontstaan van die kosmos), en antroponogie (die ontstaan van die mens binne die kosmos). Alhoewel hierdie mites grootliks verskil in terme van inhoud en hoe dit die ontstaan van die kosmos visualiseer, word die dood as deel van die opbou van die heelal deur baie van hulle uitgebeeld.

\section{Introduction}

Prompted by modern advances in our understanding of the cosmos and by studies of cosmogonic myths and mythic patterns carried out by historians of religion such as Mircea Eliade (1958, 1984; cf. Pals 2006:193-228), scholars of the ancient Mediterranean world have given renewed attention to the various cosmologies (Wright 1995) and cosmogonies of antiquity (Gregory 2007). These include the cosmologies of the ancient Near East, as well as those of ancient Greece, with the latter receiving particular attention (Spoerri 1959; Adkins 1985a, 1985b; Furley 1987, 1989, 1999; Sedley 2007; Stenudd 2011). Given the growing recognition of the 'orientalising revolution' in archaic Greece and the ways in which the ancient Near East influenced Greek thought and culture in the early archaic period (Burkert 1992), similarities and dissimilarities between the Near Eastern and the Greek cosmologies are also receiving attention (López-Ruiz 2010), as well as the various cosmologies articulated by archaic epic poets such as Hesiod (Clay 2003), by philosophers such as Anaximander (Kahn 1985), Plato (Carone 2005; Leinkauf \& Steel 2005) and Plotinus (Wilberding 2006), and by mystery religions such as Mithraism (Ulansey 1989).

Given this explosion of interest in cosmology, it may be useful to provide an overview of ancient cosmologies and cosmogonies, with the intention of providing a general cultural, mythical, philosophical and religious context for the particular Jewish and Christian cosmologies that are 
the focus of this special issue of the journal In die Skriflig/In Luce Verbi. I shall discuss 10 topics relevant to the cosmologies of the ancient Mediterranean world and make a variety of different points. These 10 topics are intentionally broad, intended to cover ancient cosmologies as a whole, and are not simply those that concern cosmology and God, namely:

- the word cosmology

- religion and cosmology

- foci within cosmology and their relevance

- cosmology and myth

- the diversity of ancient cosmologies

- different versions of the same cosmogonic myth

- cosmology, cross-cultural contact and independent local versions

- alternative intra-cultural cosmologies

- completeand partial cosmologies and their presuppositions

- comparative approaches to cosmology.

As will be readily apparent from the topics listed above, this treatment is hardly designed to be comprehensive and I give no attention at all to many fascinating ancient cosmologies, such as that found in the Derveni papyrus, which contains a commentary on an ancient Orphic theogony and cosmogony. What is striking about this work is that the author puts forth the revolutionary thesis that all the Greek deities, such as Sky, Kronos, Zeus, Earth, Ocean, Air, Mother, Rhea, Aphrodite, Fate, Harmony and Persuasion, are simply different names for 'one and the same God' (Janko 2002:3). This is an early example of what is increasingly called 'pagan monotheism' today (Athanassiadi \& Frede 1999; Yadin 2006:178-179; Mitchell \& Van Nuffelen 2010a, 2010b; Van Nuffelen 2012), and the author attempts to demonstrate that Orpheus' poem is really a cosmological allegory about the physical universe. He does so by showing how the philosophical doctrines of Anaxagoras and Diogenes of Apollonia were anticipated and taught by Orpheus. It is a fascinating though bizarre work, requiring separate treatment and more extensive discussion than is possible in this article (Betegh 2004).

I turn now to the first of the ten topics, which is devoted to the meaning and implications of the word cosmology.

\section{The word cosmology}

As is well known, the English word cosmology is a compound of two Greek words, kosmos and logos. The word kosmos fundamentally indicates 'order' (Liddell, Scott \& Jones 1996:985), a meaning that is also readily apparent in its Greek cognates, with the verb kosmeo used in the sense of 'to order, arrange' (Liddell et al. ibid:984), the noun kosmēsis indicating an 'ordering, arrangement' and 'disposition', the noun kosmètēs used for an 'orderer' or a 'director'), the adjective kosmetikos indicating someone 'skilled in ordering or arranging', and the adjective kosmētos used for something that is 'well-ordered'. Homer and other authors use the verb kosmeō militarily to indicate the act of marshalling an army, and of setting soldiers in alignment (Liddell et. al. ibid:984), the noun kosmetōr for the commander who marshals the troops, and kosmos for the resulting military alignment
(Liddell et al. ibid:985). The word kosmos was also used in the political realm to indicate governmental and institutional order. This political use of the term is seen in Herodotus, Thucydides, Democritus and Aristotle, with the first two of these employing it for the constitution of a state and the last two for types of states (Grasshoff 2003:864). But it is the use of the term by the Presocratic philosophers that is important for our purposes. They used kosmos for the order that they saw in the world at large and especially in the heavenly sphere, and for the regulated and harmonious interrelationships of things within the whole of the universe - in short, for world order.

The ancient Greeks saw beauty in order and harmony, and kosmos thus normally implies beauty, and what is beautiful is praiseworthy. That set of associated values is reflected in the use of the verb kosmeō in the sense of 'to adorn' and 'to honor' (Liddell et al. 1996:984), as well as in the use of the noun kosmos to indicate both 'ornament' and 'honor' (Liddell et al. ibid:985). The English word 'cosmetic', used especially for that which makes beautiful, whether lipstick, rouge or surgery, derives from the Greek phrase kosmettike techne, 'the art of dress and ornament' (Liddell et al. ibid:985), that is, 'adornment'.

This semantic complex has implications for our discussion of ancient cosmology. Something can exist, but if it lacks order or is in disarray, it is not a kosmos. The disorderly lacks beauty and is not praiseworthy. Troops that are milling around and not marshalled are not kata kosmon, 'in order'. The bedroom of the stereotypical teenage boy may exist, but it is rarely kata kosmon, 'in order'. The office of the stereotypical university professor, by contrast, may appear to be in utter disarray, with papers and books scattered everywhere, but the professor assures us that he or she knows exactly what is in every pile of papers and stack of books - or at least, where they are supposed to be. When applied to the universe, matter may exist, but if it is not ordered and arranged, it is not a kosmos.

From its very beginning centuries ago in the archaic Greek world, philosophy has been concerned in one way or another with the cosmos. Indeed, according to Aristotle (Metaphysica 1.2.9), it was a sense of 'wonder' (to thaumazein) about the orderliness of the world that prompted the Presocratic philosophers to launch their inquiries. Profoundly curious about nature (physis) and the physical universe (kosmos), they gave attention to the sun, moon and stars, including such phenomena as eclipses (Fitzgerald in press). Ever since cosmology has been concerned with the order of the universe, as well as occasional instances of apparent disorder, and to give a cogent account of it.

That brings us to our second Greek word in cosmology, namely, logos. As is well known, it has two basic senses, both of which have been used when speaking of the cosmos. The first of these senses is 'word' or 'speech', and the second is 'thought' or 'reason' (see Liddell et al. 1996:1057-1059, which gives a range of meanings). Useful discourse about the cosmos should not be mindless babble, but rather reflect the 
use of one's mental faculties. This gives us the first of two primary ways in which the term cosmology has been used, namely of 'a reasoned account of the order of the universe' (Campbell 2006:239). Emphasis here falls upon the reasons or grounds for saying what one does about the cosmos. This is how modern cosmologists use the term and where they place their emphasis. In discussing the cosmos, modern science places emphasis on three things: reason, observation and verification of observations by testing. That is perfectly appropriate for what they are endeavouring to do. There is, however, a second way in which the term cosmology has been used which is of particular interest to biblical scholars and theologians. This has to do with the use of cosmology to indicate 'the study of the reason or mind behind the order of the universe' (Campbell ibid:239), and, because this mind or reason is often understood theistically, it links theology and cosmology, which is the particular concern of this issue of the journal. This close linkage between cosmology and theology leads to the second major topic.

\section{Religion and cosmology}

All ancient or traditional cultures have a cosmology of some kind and these cosmologies are invariably religious in nature, or constitute a reaction to, or reinterpretation of a prior religiously conceived cosmology (Durkheim 2001:10; Green 2010). The two-fold corollary to this pervasive and reciprocal relationship of religion to ancient cosmology is, firstly, that one cannot understand ancient cosmologies without understanding the religions that produced them, and secondly, one cannot understand ancient religions without giving attention to their cosmologies. Needless to say, this is particularly true for both ancient Israelite religion and for early Christianity. Consequently, if we wish to understand them, we have to understand their cosmologies. This is especially so for Jewish and Christian creation narratives, because 'every creation myth is soteriological as well as cosmogonical' (Smith 1993:96, referring to the work of Eliade and Sigmund Mowinckel).

\section{Foci within cosmology and their relevance}

Ancient cosmologies may provide a description of the current cosmos, as well as an explanation for its coherence as a whole, but that is rarely their focus. Their concern is much more with the origins of the cosmos and of humans within it. That is, cosmology in the ancient world often includes cosmogony, the genesis of the cosmos, and sometimes anthropogony, the origin of humans within this cosmos. Given the religious nature of ancient cosmology, it often includes theogony (the genesis of the divine) or at least indicates the relationship of the divine to the cosmos. In short, in ancient cosmologies there is often an overlapping intersection of theogony, cosmogony and anthropogony. One of the reasons why the peoples of the ancient world rehearsed the myths of their primeval origins was etiological, since these myths provided an explanation for the current state of affairs - for the way things are now. But the rehearsal of this primordial history was not merely etiological, but also sociological and ethical, for it was intended to provide what the renowned anthropologist Bronislaw Malinowski called a social 'charter' of conduct for the society as a whole, as well as for individuals within it (Malinowski 1926). Ancient cosmology is in this sense paradigmatic for the cultural or religious group that embraces it, having 'important social, material, and economic ramifications as well as deep religious significance' (Lincoln 1975:121). For a group to articulate a cosmology is thus to give expression to its understanding of itself, of the world in which it lives, and of its relationship to both that world and to the divine (Wright 2006:755-756).

It is not without interest that the theme of death occurs in many ancient cosmologies. Indeed, in cosmogonies, even gods may die and death becomes the destiny of humanity. 'This tragic element explains the finitude of human community and introduces death as a cosmogonic structure of human existence' (Long 1987:98). Some ancient myths, such as the Gilgamesh Epic, depict the attempt to escape this destiny and some ancient religions offer the hope of success in the accomplishment of this task.

\section{Cosmology and myth}

Myth is the oldest form in which ancient cosmologies are stated and these cosmological myths are quite old. They are in fact amongst the oldest narratives that we possess. We have, inter alia, cosmological and cosmogonic myths from ancient Egypt, ancient Mesopotamia, ancient Israel, ancient Greece and ancient India. It seems relatively certain that one such creation myth is Proto-Indo-European in origin, and that this Ur-myth narrated the creation of the cosmos by sacrifice, a myth of origins in which 'a primordial being is killed, dismembered, and from his body the cosmos is fashioned' (Lincoln 1975:128). A late form of this myth appears in Norse mythology, in which Ymir, a primordial being born from venom and who gives birth to a male and a female from the pits of his arms, is killed and three gods fashion the world from his corpse (Lincoln ibid):

[F]rom his blood the sea and lakes, from his flesh the earth, from his bones the mountains; rocks and pebbles they made from his teeth and jaws and those bones that were broken. (p. 128)

As the Ymir episode indicates, violence of some sort is often a feature of cosmogonic, theogonic and anthropogonic myths, though it is certainly not present in all such myths. Indeed, the absence or deletion of acts of violence may be one way of culturally intensifying or making conspicuous the power of the head of the pantheon or of the creator god. In contrast to myths of violence in which the younger gods have to acquire their power by warfare, non-violent myths may function to say implicitly that 'our god' has always had and will always retain power, and will reign forever.

\section{The diversity of ancient cosmologies}

When viewed globally, the variety of cosmologies and cosmogonies is staggering. Charles H. Long (1963), in his classic anthology of myths of creation, identifies six different 
types of myths according to their symbolic structures (for a condensed treatment, see Long 1987). They include:

1. Emergence myths, in which the symbolism of gestation and birth is used to depict the cosmos appearing through mother earth. In contrast to myths of violence, emergence myths typically depict a 'harmonious relationship among all the forms of the created order' (Long 1987:97).

2. World-parent myths, in which the parents may be indifferent or even hostile to their offspring's needs and desires, leading to inter-generational conflict (Long 1987:96).

3. Creation from chaos, with chaos often depicted as a serpentlike monster. Cosmic order entails the overcoming of this monster. 'In some myths of this type,' however, 'the chaos is never completely overcome ... vestiges of the chaos remain and the created order is always in danger of slipping back into chaos' (Long 1987:95).

4. Creation from a cosmic egg, which occurs in ancient Orphism, with Time fashioning or generating an egg from which Protogonos, the First-born who is identified with Phanes-Dionysus, appeared (Long 1963:123-124; cf. West 1983:198-207).

5. Creation ex nihilo, that is, creation from nothing.

6. Earth-diver myths, in which a god, cultural hero, or even an animal dive into the primordial waters and bring up particles of earth, mud or sand, out of which an ordered cosmos begins to appear (Long 1987:97).

As these six types of creation myths illustrate, diversity rather than uniformity is the norm as far as ancient cosmology is concerned (cf. Sproul 1979; Smith 1982:66-90, 96-101, 149-154).

There is even diversity regarding the centre of the universe. The ancients may have debated the shape of the earth, with some asserting that it was a disk and others a sphere, but they usually agreed that the earth, whatever its precise shape, was the centre of the universe. However, here were exceptions to this almost universally affirmed geocentric cosmos, with the most important of these exceptions being Aristarchus of Samos, an astronomer and pupil of the Aristotelian philosopher Straton of Lampsacus. Aristarchus flourished about 280 BCE and postulated a heliocentric universe. In his view, 'the fixed stars and sun remain unmoved, and ... the earth revolves around the sun on the circumference of a circle, the sun lying in the middle of the orbit' (Toomer 1996:159, quoting the relevant passage of Aristarchus preserved by Archimedes, Arenarius [also known as Psammites or Sandreckoner] 4-5). That remarkable hypothesis was formulated more than 1800 years before Copernicus who in 1543 postulated a heliocentric planetary system in his book On the revolution of heavenly spheres, and long before the invention of the telescope, probably by Hans Lippershey at the beginning of the seventeenth century.

\section{Different versions of the same cosmogonic myth}

Some ancient cosmogonic myths have family resemblances, so that we possess different versions or renditions of the same basic myth. These myths, though authoritative, had a certain elasticity that enabled them to be appropriated, adapted and used by different groups. One illustration of this phenomenon is the famous Enuma Elish, the epic of creation that has often been compared and contrasted with the creation story found in Genesis 1. Its precise date of composition is unknown, though there is a broad consensus that the work dates from the second millennium BCE (Foster 2005:436). The epic exists in two versions, one Babylonian and one Assyrian. The Babylonian version is usually regarded as the older of the two, and it narrates the elevation of the Babylonian god Marduk to supreme power. This elevation happens with the voluntary consent of the older deities over whom Marduk will reign and is actualised when he, following his coronation, succeeds in defeating Tiamat, the primeval mother ocean who, together with Apsu, had existed before all else. Beginning with the bisection of Tiamat, Marduk proceeds to create the cosmos, establishing the sky, organising the stars and planets and marking off the years. He returns in triumph and creates Babylon as the earthly counterpart to Esharra, the gods' abode in heaven. The elevation of Marduk thus entails the elevation of Babylon as the terrestrial city of the gods. This epic was recited as part of the New Year Festival in Babylon, when 'the king had his mandate to rule renewed by the gods' (Dalley 1989:232). Those present on that occasion renewed their oaths of loyalty to the king, just as the gods had once sworn loyalty to Marduk. Within this context, the recitation of the creation myth had a clear political function (Dalley ibid) - it showed the kings:

how an orderly universe and its kingship should be organized ... When the king's subjects kiss his feet, they are doing no less

than the great gods of heaven and earth did for Marduk. (p. 232)

In the Assyrian recension of this same myth, Assur, the chief god of the city of Assur (Ashur), one of the ancient capitals of Assyria, replaces Marduk (Foster 2005:436). Now the myth functions to chronicle the rise to power of Assur and Assyria and, like the Babylonian original, it was used in that religious context for the same political purpose. Indeed, the Assyrian king Sennacherib decorated the doors of the Temple of the New Year Festival with scenes from the Enuma Elish (Dalley 1989:275, n. 21). As this recycling and updating of the old creation myth indicates, the names of even the divine heroes can change, but the function will often remain the same.

\section{Cosmology, cross-cultural contact and independent, local versions}

Different cultural versions of the same cosmological myth, family resemblances of two or more myths and the occurrence in different myths of the same or similar episodes and motifs are partly explicable in terms of cultural contact and exchange. The affinities between ancient Near Eastern myths and Greek myths, for example, suggest contact during the 'orientalizing revolution' (Burkert 1992) in Greek history, when there was substantial contact in art, myth and philosophy. For instance, 'various Hittite mythical texts present striking parallels with certain features and episodes of Hesiod's Theogony' (Most 2006:xxxv). Indeed, 
they 'recount a myth of succession in heaven, including the castration of a sky-god, the apparent eating of a stone, and the final triumph of a weather-god corresponding to Zeus' (Most ibid:xxxv). Whilst an explanation in terms of cultural contact and transmission seems likely in this case, in others the similarities may simply be independent occurrences of the same motif or action. Methodological caution is thus always prudent in explaining similarities.

\section{Alternative intra-cultural cosmologies}

Not only can cosmological myths be appropriated from other groups, but different such myths can co-exist within a given culture. Indeed, one of the most striking aspects of ancient cultures is their ability to operate with narratives and mythic explanations that are logically contradictory and exist in some tension with one another. Despite that fact, each version can have authoritative, even normative status. As is well known, the biblical book of Genesis opens with two different cosmogonic myths, one found in chapter $1: 1-2: 4 a$, and the other in chapter $2: 4 b-25$. In terms of traditional source criticism, the former is typically assigned to the Priestly source (P), the latter to the Yahwistic source (J). God creates in P by speaking, whereas in J, God is depicted anthropomorphically, creating both the man (the adam) and the animals out of the ground (adamah), breathing the breath of life into the nostrils of the newly formed man and later surgically removing one of his ribs in order to fashion from it the woman. In P, man and woman are created simultaneously in God's own image and their creation takes place after the animals that inhabit the sky, sea and land have been created. In J, by contrast, the man is created prior to both the animals and the woman, and the woman is created as the man's mirror image (Gn 2:18). In $\mathrm{P}$ we are repeatedly told that what God did in creating and ordering the world was 'good' (Gn 1:4, 9, 12, 18, 21, 25) and 'very good' (Gn 1:31), whereas in $\mathrm{J}$ the only evaluative comment is that it was 'not good' (Gn 2:18) for the man to be alone.

Additional differences could be noted, but this suffices to indicate that we have here two different cosmogonic, anthropogonic myths. Therefore, it is striking that the editor of Genesis juxtaposed them. Whatever problems later interpreters may have with these two different versions, or whatever exegetical fodder they provided for a Platonically-minded interpreter such as Philo in his De opificio mundi [On the creation of the world], the editor of Genesis was happy to present both versions side by side. Such is the nature of myth.

Genesis, however, is not at all unique in doing this. We see the same phenomenon in ancient Egypt, which, like ancient Israel and other cultures of the ancient Near East, operated with a three-tiered conception of the universe. That is, they conceived of the universe as having three basic structures: the earth, with the heavenly realm or sky above, and the netherworld below. Yet, in depicting this threetiered universe, the Egyptians used four different models
(Wright 2006:756). The first was the 'celestial bird' model in which a vast cosmic falcon, identified as Horus, was conceived as hovering over the earth, with the sun and moon serving as the falcon's eyes. The second was the 'celestial cow' model in which the goddess Hathor, depicted as a cosmic cow, stood over the earth. The third was the 'celestial woman' model, with the goddess Nut arching over the earth, balancing herself by using both her hands and feet. The fourth was a 'celestial plane' model, with the cosmos conceived as a flat or convex plane. In addition to using these four cosmological models, the Egyptians also conceived of a vast cosmic river flowing through the cosmos. As is immediately evident, conceptions of the divine play a key role in the Egyptians' imagining of the cosmos and as the belief in a cosmic river suggests, their own experience of the Nile river flowing through the land of Egypt was projected onto the cosmos as a whole. What is true of the Nile is true of their cosmologies as a whole: 'the many and varied Egyptian cosmologies all reflect Egyptian society and values by projecting onto the transcendent realms the patterns and structures of Egyptian society' (Wright ibid:756). What sustains these multiple cosmologies, despite the fact that they contradict one another at key points, is that each cosmology reflects and inculcates different aspects of a given culture's human experience, including its religious experience, as well as its social world.

\section{Complete and partial cosmologies and their presuppositions}

As previously indicated, ancient cosmology, broadly conceived, encompasses not only cosmology per se, but also theogony, cosmogony and anthropogony. The Enuma Elish, for instance, contains a theogonic succession myth, followed by a cosmogonic account of the genesis of the cosmos that explains why, for instance, the moon now rules the night and why there are 12 months in a year, and it ends with an anthropogonic myth of the creation of human beings from the blood of Qinqu, a myth that also provides a reason for the creation of humans, namely to bear the burden of the gods so that they may rest. Yet, not all ancient authors and texts provide a complete cosmological account. In Hesiod's Theogony (also known as Theogonia), for example, we have no anthropogonic narrative, only a theogony and cosmogony. Humans are explicitly mentioned in the Theogony, but neither here nor in the later Works and Days (also known as Opera et dies) does Hesiod narrate a myth that tells us how humans came into existence. He is content to simply assert what the human lot in life is. Thus, whereas the two Genesis accounts of creation presuppose the existence of God, Hesiod presupposes the existence of humans (Blundell 1986:4, 9).

\section{Comparative approaches to cosmology}

The sheer existence of multiple ancient cosmologies invites, if not requires, a comparative approach by which the similarities and differences may be noted and used to highlight the distinctiveness of each cosmology. This comparative approach can be illustrated by two examples. 
Firstly, as already indicated, in the Babylonian version of the Enuma Elish, Marduk proposes the creation of humans for the specific reason that the gods may have rest. He shares his idea with his father Ea, saying:

I shall compact blood, I shall make bones to be,

I shall make stand a human being, let 'Man' be its name.

I shall create humankind,

They shall bear the gods' burden that those may rest. (VI.5-8) ${ }^{1}$

Ea responds by giving him 'a plan to let the gods rest' (VI.12) that will involve forming humans from Qinqu's blood. The text continues: 'After Ea the wise had made humankind, they imposed the burden of the gods on them' (VI.35-36).

A Sumerian and Akkadian account of the creation of humans complements the Babylonian account by giving a fairly complete idea of what Marduk had in mind and includes the following lines (Creation of Humankind, lines 27, 29, 31, 33-35, $7^{\prime}-8$ '; Foster 2005):

To maintain the boundary ditch for all time,

To make the great dwelling of the gods,

To add field to field!

To regulate irrigations works,

To water the four abodes (of the earth),

To make the plant life flourish.

To increase cattle, sheep, wild beasts, fish and birds,

For prosperity in the land. (p. 492-493)

The idea of divine rest recalls the P account in Genesis 1-2:4a, which ends with God resting on the Sabbath (Gn 2:3), thus enshrining the observance of the Sabbath in the cosmic structure of the world. Therefore, the same motif of divine rest is present in both the Enuma Elish and Genesis 1, but not without striking differences. In Genesis, God rests following the creation of humans, but humans are not created to spare God the toil of further activity. Moreover, God rests only on the Sabbath, not perpetually, and remains active in the world as salvation history unfolds. Furthermore, humans' activities only become laborious in Genesis 3, in punishment for their disobedience regarding the tree of the knowledge of good and evil. In the Enuma Elish, by contrast, there is no primordial time when humans enjoy a godlike existence from their very creation the human lot is hard labour.

The second example of comparative approaches to cosmology is closely related to the first. J's depiction in Genesis 2 of a primordial paradise in Eden prior to the Fall has an analogy in the Greek tradition, which in a similar way thought of an initial time in the early history of the cosmos when humans enjoyed a different relationship with the divine than is currently the case. For example, this idea of primordial human bliss also appears in Hesiod. In his account of the five races, or ages, of humans, the first race (the golden one) has a different relationship with the gods. This is because, Hesiod avers, humans derive from the same source as the gods (Opera et dies (Op.) 108), and existed together with the gods during the reign of Kronos. Hesiod says of the golden race that:

[J]ust like gods, they spent their lives, with a spirit free from care, entirely apart from toil and distress. Worthless old age 1.Ail translations of the Enuma Elish are those of Foster (2005). did not oppress them, but they were always the same in their feet and hands, and delighted in festivities, lacking in all evils. (Op. 112-115; see also Op. 90-92) ${ }^{2}$

Furthermore, crops grew of their own accord, making it unnecessary for them to take thought for the future (Op. 116-120).

In short, the only meaningful difference between gods and men was that humans were mortal and thus died, whereas the gods were immortal and did not die. The death experienced by golden race men was not harsh, but gentle, 'as if overpowered by sleep' (Op. 116). A line from one of the fragments of Hesiod adds that 'banquets then were shared, seats were shared by immortal gods and mortal men' (Blundell 1986:5, frg. 1). This glorious primordial age and the joyous custom of gods dining together with the golden race of humans ended soon after Zeus succeeded Kronos. Humans were not responsible for rupturing the divine-human relationship; it was rather the god Prometheus who caused the rupture by tricking Zeus into choosing the inferior of two ox portions. Instead of selecting the portion with the flesh and fat, Zeus chose the one with the ox's bones (Theogonia 533-557). The result was two-fold. Firstly, humans received the other ox portion, the one with ox-meat, and this apparently transformed them into carnivores (Blundell ibid:4-5), whereas previously they had been vegetarians - as were Adam and Eve in Eden (see Gera 2003:57-61 for Golden Age vegetarianism). Secondly, Prometheus' trickery had significant cultic consequences for humans: 'And ever since then the tribes of human beings upon the earth burn white bones upon smoking altars for the immortals' (Theogonia 556-557). This is the inception of sacrifice, and as the classicist Sue Blundell (ibid:5) remarked: 'Sacrifice marks the point when the human race becomes distinguished from that of the gods and ceases to enjoy divine privileges.'

Sacrifice also occurs in Genesis, where the very first story following the expulsion of Adam and Eve from the Garden of Eden, is the account of their sons Cain and Abel offering sacrifices to God. This very act of sacrifice by the two brothers is one of the narrative's indications that life outside of paradise is fundamentally different from life in it, and it is comparative mythology that helps us realise and appreciate this aspect of the story.

\section{Conclusion}

In conclusion, there is not one ancient cosmology, but rather multiple cosmologies exist, each offering a different account of the universe and of humans within it. Early Christianity arises within the context of these multiple and competing cosmologies and it adds its own cosmologies and cosmogonies to the mix. Its key addition, of course, is none other than Christ himself, in whose name all of the cosmologies it inherits and adopts are transformed. Precisely how that transformation occurs, the various shapes it assumes and how Christians relate their cosmology to their theology, Christology and anthropology are the concern of other papers published in this issue of the journal.

2.Unless otherwise indicated, translations of Hesiod are by Most (2006) 


\section{Acknowledgements Competing interests}

The author declares that he has no financial or personal relationship(s) that may have inappropriately influenced him in writing this article.

\section{References}

Adkins, A.W.H., 1985a, 'Cosmogony and order in ancient Greece', in R.W. Lovin \& F.E. Reynolds (eds.), Cosmogony and ethical order: New studies in comparative ethics, pp. 39-66, University of Chicago Press, Chicago.

Adkins, A.W.H., 1985b, 'Ethics and the breakdown of the cosmogony in ancient Greece', in R.W. Lovin \& F.E. Reynolds (eds.), Cosmogony and ethical order: New Greece, in R.W. Lovin \& F.E. Reynolds (eds.), Cosmogony and ethical order: New
studies in comparative ethics, pp. 279-309, University of Chicago Press, Chicago.

Athanassiadi, P. \& Frede, M. (eds.), 1999, Pagan monotheism in Late Antiquity, Clarendon, Oxford.

Betegh, G., 2004, The Derveni papyrus: Cosmology, theology, and interpretation, Cambridge University Press, Cambridge. http://dx.doi.org/10.1017/ CBO9780511584435

Blundell, S., 1986, The Origins of civilization in Greek and Roman thought, Croom Helm, London.

Burkert, W., 1992, The orientalizing revolution: Near Eastern influence on Greek culture in the early archaic age, Harvard University Press, Cambridge.

Campbell, G., 2006, 'Cosmology', in G. Shipley, J. Vanderspoel, D. Mattingly \& L. Foxhal (eds.), The Cambridge dictionary of classical civilization, pp. 239-240, Cambridge University Press, Cambridge. PMid:16804517 PMCid:2360610

Carone, G.R., 2005, Plato's cosmology and its ethical dimensions, Cambridge University Press, New York. http://dx.doi.org/10.1017/CBO9780511734915

Clay, J.S., 2003, Hesiod's cosmos, Cambridge University Press, Cambridge. http:// dx.doi.org/10.1017/СВ09780511482397

Dalley, S., 1989, Myths from Mesopotamia: Creation, the flood, Gilgamesh, and others, Oxford University Press, Oxford.

Durkheim, É., 2001, The elementary forms of religious life, transl. C. Cosman, Oxford University Press, New York.

Eliade, M., 1958, 'The Prestige of the cosmogonic myth', Diogenes 6(23), 1-13. http:// dx.doi.org/10.1177/039219215800602301

Eliade, M., 1984, 'Cosmogonic myth and "sacred history"', in A. Dundes (ed.), Sacred narrative: Readings in the theory of myth, pp. 137-151, University of California Press, Berkeley.

Fitzgerald, J.T., (in press), 'Greco-Roman philosophical schools', in J.B. Green \& L.M. McDonald (eds.), The World of the New Testament: Cultural, social, and historical contexts, ch. 10, Baker Academic, Grand Rapids.

Foster, B.R., 2005, Before the muses: An anthology of Akkadian literature, 3rd edn. $C D L$, Bethesda.

Furley, D.J., 1987, The Greek cosmologists, Cambridge University Press, Cambridge. http://dx.doi.org/10.1017/CBO9780511552540, PMCid:305234

Furley, D.J., 1989, Cosmic problems: Essays on Greek and Roman philosophy of nature, Cambridge University Press, Cambridge.

Furley, D.J., 1999, 'Cosmology', in A. Keimpe, J. Barnes, J. Mansfeld \& M Schofield (eds.), The Cambridge history of hellenistic philosophy, pp. 412451, Cambridge University Press, Cambridge. http://dx.doi.org/10.1017/ CHOL9780521250283.013

Gera, D.L., 2003, Ancient Greek ideas on speech, language, and civilization, Oxford University Press, New York. http://dx.doi.org/10.1093/acprof:o so/9780199256167.001.0001

Grasshoff, G., 2003, 'Cosmology', in H. Cancick \& H. Schneider (eds.), Brill's new Pauly: Encyclopedia of the ancient world, Brill, Leiden, vol. 3, cols. 864-871.
Green, W.S., 2010, 'A "humanly relevant" cosmos: What we study when we study religion', in J. Neusner (ed.), Introduction to world religions, pp. vii-xxiii, Abingdon, Nashville.

Gregory, A., 2007, Ancient Greek cosmogony, Duckworth, London.

Janko, R., 2002, 'The Derveni papyrus: An interim text', Zeitschrift für papyrologie und epigraphik 141, 1-62.

Kahn, C.H., 1985, Anaximander and the origins of Greek cosmology, Centrum Philadelphia, Philadelphia.

Leinkauf, T. \& Steel, C.G. (eds.), 2005, Platons Timaios als grundtext der kosmologie in Spätantike, Mittelalter und Renaissance [Plato's Timaeus and the foundations of cosmology in Late Antiquity, the Middle Ages and Renaissance], Leuven University cosmology in Late
Press, Leuven

Liddell, H.G., Scott, R. \& Jones, H.S. (eds.), 1996, A Greek-English lexicon: With a revised supplement, Clarendon, Oxford.

Lincoln, B., 1975, 'The Indo-European myth of creation', History of Religions 15(2), 121-145. http://dx.doi.org/10.1086/462739

Long, C.H., 1963, Alpha: The Myths of creation, Braziller, New York.

Long, C.H., 1987, 'Cosmogony', in M. Eliade (ed.), The Encyclopedia of religion, vol. 4 pp. 94-100, Macmillan, New York.

López-Ruiz, C., 2010, When the gods were born: Greek cosmogonies and the Near East, Harvard University Press, Cambridge.

Malinowski, B., 1926, Myth in primitive psychology, Norton, London.

Mitchell, S. \& Van Nuffelen, P. (eds.), 2010a, Monotheism between pagans and Christians in Late Antiquity, Peeters, Leuven. http://dx.doi.org/10.1017/ CBO9780511730115

Mitchell, S. \& Van Nuffelen, P. (eds.), 2010b, One god: Pagan monotheism in the Roman Empire, Cambridge University Press, Cambridge.

Most, G.W. (transl.), 2006, Hesiod: Theogony, Works and Days, testimonia, Harvard University Press, Cambridge.

Pals, D.L., 2006, Eight theories of religion, 2nd edn., Oxford University Press, New York. PMCid:1860722

Sedley, D.N., 2007, Creationism and its critics in antiquity, University of California Press, Berkeley.

Smith, J.Z., 1982, Imagining religion: From Babylon to Jonestown, University of Chicago Press, Chicago.

Smith, J.Z., 1993, Map is not territory: Studies in the history of religions, University of Chicago Press, Chicago.

Spoerri, W., 1959, Späthellenistische berichte über welt, kultur und götter, Reinhardt, Basel. PMid:13628522

Sproul, B.C., 1979, Primal myths: Creation myths around the world, Harper \& Row, San Francisco.

Stenudd, S., 2011, Cosmos of the ancients: The Greek philosophers on myth and cosmology, Arriba, Malmö. PMid:21809526

Toomer, G.J., 1996, 'Aristarchus (1)', in S. Hornblower \& A. Spawforth (eds.), The Oxford classical dictionary, 3rd edn., p. 159, Oxford University Press, Oxford

Ulansey, D., 1989, The origins of the Mithraic mysteries: Cosmology and salvation in the ancient world, Oxford University Press, New York.

Van Nuffelen, P., 2012, "Beyond categorization: "Pagan monotheism" and the study of ancient religion', Common Knowledge 18(3), 451-463. http://dx.doi. org $/ 10.1215 / 0961754 X-1630332$

West, M.L., 1983, The Orphic poems, Clarendon, Oxford.

Wilberding, J., 2006, Plotinus' cosmology: A study of Ennead II.1 (40). Text, translation, and commentary, Oxford University Press, Oxford.

Wright, J.E., 2006, 'Cosmogony, cosmology', in K.D. Sakenfeld (ed.), The new interpreter's dictionary of the Bible, vol. 1, pp. 755-763, Abingdon, Nashville.

Wright, M.R., 1995, Cosmology in antiquity, Routledge, London.

Yadin, A., 2006, 'Rabban Gamliel, Aphrodite's bath, and the question of pagan monotheism', The Jewish Quarterly Review 96(2), 149-179. http://dx.doi. org/10.1353/jqr.2006.0015 